\title{
Counter-Imagination as Interpretive Practice: Futuristic Fantasy and The Fifth Element
}

\author{
Brian L. Ott and Eric Aoki
}

This essay concerns the relationship between popular cinematic visions of the future and present day identity politics. We argue that despite its futuristic setting celebrating technological progress and multiculturalism, Luc Besson's 1997 film The Fifth Element constructs sexual and racial difference in a manner that privileges and naturalizes White heterosexual masculinity. The essay offers counter-imagination as an interpretive practice that destabilizes the categories of sexual and racial difference as they are negotiated within appeals to popular imagination.

In contemporary scholarship, appeals to a shared sense of the past or collective memory are generally regarded as intensely political.' The cultural, educational, and political narratives that shape collective memory, though always incomplete, are structured to hide their silences and their singularity of perspective. Indeed, such narratives successfully perform their ideological work precisely because they cloak themselves in a discourse of universality and absolute truth. It is as much what these narratives do not speak, what they cannot speak, that functions to reinforce a particular set of social relations in which some views, values, and voices are legitimated while others are marginalized or erased. With the recognition that invitations to collective memory are increasingly mediated in a postmodern landscape, film critics have been attentive to the representational politics of historical films as diverse as Guilty by Suspicion (1991), JFK (1991), and Schindler's List (1993). ${ }^{2}$ Critics have tended not, however, to exercise the same degree of scrutiny with regard to non-historical films, and in particular those that attempt to craft a shared vision of the future, despite Hollywood's aggressive efforts in this arena.

\footnotetext{
Brian L. Ott (Ph.D., The Pennsylvania State University) and Eric Aoki (Ph.D., University of Washington) are both Associate Professors in the Department of Speech Communication at Colorado State University. They contributed equally to this essay. An earlier version of this essay was presented at the 2000 Film and Video conference, Colorado State University, Fort Collins, CO, March 17, 2000. The authors wish to thank their students for inspiring them to write this essay and the anonymous reviewers for their helpful comments on previous drafts.
} 
From the dystopian neon jungle of Blade Runner (1982) to the simulated cyberscape of The Matrix (1999), Hollywood, it would seem, is determined to show us the future. Although it is tempting to dismiss this perennial obsession with the future as pure fantasy and mere escapism, such an outlook fails to account for how science fiction films invite audiences to participate in collective visions of the future, how such appeals to "popular imagination" (Ott \& Aoki, 2001, p. 394) inform our socio-political landscape, and how every cinematic performance of the future is a structuring of perception and being in the present. Of particular significance are the questions of difference at work in science fiction (SF). "[The] contemporary science fiction film," argues Penley (1991), "consciously and unconsciously constructs new categories of masculinity and femininity ... through the shifting, ambiguous, and contradictory sexual status it assigns the robot, the alien, the monster, or even elements of the futuristic mise en scène" (italics in original, pp. vii-viii). Given its experimentation with categories of sexual (and racial) difference, the science fiction genre is of special import to feminist scholars and teachers. It affords a unique opportunity to engage and assess alternative models of subjectivity, as well as to develop interpretive practices for resisting social structures of inequality. ${ }^{3}$

With a price tag of over $\$ 90$ million and a recent airing on prime-time television, Luc Besson's 1997 film, The Fifth Element, ranks among Hollywood's most aggressive and widely circulated attempts at structuring popular imagination, and thus provides an excellent vehicle to begin examining the relationship between future-oriented science fiction and contemporary identity politics. Employing an oppositional approach rooted in psychoanalytic, race, and queer theories, we assert that The Fifth Element fashions sexual and racial difference in a manner that functions to naturalize and perpetuate existing social structures of inequality and oppression. Specifically, the film privileges White heterosexual masculinity by constructing it as "universal protector" in relation to the distressed categories of femininity and alien Other. To illustrate this claim, we offer the notion of counter-imagination-an interpretive practice that seeks to disrupt the hegemonic structuring of difference within the context of appeals to popular imagination. Like Nakayama (1994) and hooks (1989), we maintain that domination cannot be understood by a single category of analysis and must rather be interrogated across intersecting vectors of power, such as gender, race, and sexuality. 


\section{Counter-Imagination as Interpretive Practice}

"What is a film doing and how?" are among the most difficult and frustrating questions a critic can pose of any film. The answers to these questions seem, at times, as varied as a film's viewers, and yet films have the remarkable ability to arouse similar emotions and experiences in audiences. These shared experiences arise despite viewers' idiosyncratic impressions because films, as social constructions, draw upon culturally internalized symbols. Thus, by interrogating a film's "constructed invitation" (Benson \& Anderson, 1989, p. 3), critics can reasonably provide an account of the shared experience a film fosters. One of the central ways that films function as structured invitations is by creating subject positions with which viewers are solicited to identify. Brummett (1994) explains the process this way:

[A] subject position is not a character in the text itself. Instead, a subject position is who the text encourages you to be as you, the reader or audience, experience that text. Rarely will a text explicitly announce its preferred subject position for the members of its audience. Instead, a subject position, like narrative, is part of the structure of a text ... the missing perspective, the point of view, required for the text to make sense. (Italics in original, p. 98)

Subject positions, then, discipline audiences to view films and subsequently the world from particular perspectives. The consistent and ubiquitous affirmation of certain subject positions across media functions to foster and sustain a particular set of social relations by privileging and authorizing certain viewpoints and subjectivities over others. In other words, as a collectivity, films have the power to frame the way we view ourselves, our relation to others, and the social world around us.

Although films invite preferred subject positions, audiences can always choose to reject them in favor of subversive stances, provided that they have access to oppositional codes. ${ }^{4}$ Such codes highlight the taken-forgranted patterns within messages-patterns that function ideologically to reinforce prevailing social structures. By employing oppositional codes, audiences are equipped to "see through" the dominant ideology of a message, and to envision their subjectivities outside the boundaries dictated by that message. Marxist and feminist interpretive strategies (codes) 
are vital, for instance, to disrupting the ways in which a capitalistic, patriarchal film interpellates its viewers. Seeking to equip students with the codes needed to deconstruct the ideologies that too frequently animate Hollywood's futuristic fantasies, we propose an interpretive practice of "counter-imagination." Such a practice aims to facilitate notions of a "radical democracy" by assisting political subjects in viewing their subjectivities as products of specific representational practices, rather than as reflections of the natural world. ${ }^{5}$

As a reading practice, counter-imagination is not a wholly new critical construct. Like the many existing principles for reading mediated texts oppositionally, it is centrally concerned with unmasking deep ideological structures and the relations of power they serve. ${ }^{6}$ Where it extends existing counter-hegemonic principles is in its careful attention to the unique characteristics of science fiction, especially future-oriented SF, and the subject positions encouraged by that class of messages. As a genre, works of science fiction are rooted in distortion-some "discontinuity between the worlds they present to us and the world of our experience" (Scholes, 1975, p. ix). In (re)presenting alternate(ive) realities, SF narratives envision new beings and landscapes (Penley, 1991). But they are 'new' only in the sense that they are less familiar, as science fiction turns on mutation and metamorphosis of existing codes and categories. Nevertheless, through its creative (re)combinations, SF offers unusual, hybridized identities and strange, foreign landscapes. The precise manner in which these 'new' identities and landscapes distort 'the familiar' functions both to demystify some social structures and to further naturalize others. The appearance of an outwardly multicultural corporation in a SF story, for instance, might highlight a lack of diversity in contemporary U.S. corporate culture even as it obscures the social practices that sustain such inequity. Counter-imagination, then, specifically focuses on the distortions in SF, and what they communicate about sexual and racial difference.

Among the most common vehicles of distortion in SF is the future. Narratives of the future show us a world that could be, or in the case of utopian appeals to popular imagination a world that ought to be (Ott \& Aoki, 2001, p. 395). Visions of the future forecast a social system dissimilar to our lived present, but they do not imagine the "real" or certain future. The diverse mock futures of science fiction are only potentialities, and their ideological significance lies not in what they suggest we "actually" will become, but in the ways that they transform, explains Jameson (1982), "our own present into the determinate past of 
something yet to come" (p. 152). Appeals to a shared sense of the future are also invitations to a collective vision of the present-a vision SF renders as a remote past. Future-oriented science fiction fixes a particular image of the present as history, as finished and intelligible, as a base from which its futuristic social system naturally developed. A resistive reading of representations of the future, then, involves exposing the unspoken assumptions such images make about who and what we are in the present. The vision of an ultra high-tech future (irrespective of its optimism or pessimism concerning that set of images), for example, testifies to a fascination with and privileging of technology in the past (i.e., our present) just as a low-tech future would diminish technology's perceived importance in the modern collective imagination. If we add a level of complexity to this example by-noting that technology is defined primarily in masculine terms in this high-tech future, then the images naturalize masculinity as central to the advance of technological progress.

By denaturalizing SF's futuristic images-by exposing the cultural assumptions underlying its distortions-counter-imagination creates an ideological rupture, one that unsettles the subject in language. This "loss of self" (Fiske, 1989, p. 50), this "mode of vanishing, of annulment of the subject" (Barthes, 1985, p. 173) is where the liberatory potential of any oppositional reading practice resides. When language is no longer $r e$ ceived, when the whole apparatus of the Author-God is disrupted, text construction (and hence the ability to envision new subjectivities) becomes "the primary task of audiences, readers" (McGee, 1990, p. 274; see also Barthes, 1988b). Hence, counter-imagination (as well as other counter-hegemonic reading practices) must constantly guard against method and prescription. Counter-imagination reflects an attitude (of suspicion) toward future-oriented science fiction, but it does not and ought not advocate a rigid, overly systematized approach or prescribe a particular set of alternative subjectivities. It is neither our desire nor our hope to identify a reading practice that can be replicated or to envision an "ideal" future. Such a move would do little more than create its own stereotype, leaving "the door wide open for ideology" (Barthes, 1985, p. 174). If all future-oriented SF was read according to the same procedure with a particular vision of the future in mind, it would simply (re)produce a new dominant ideology (and subjectivities). What, after all, is dominant ideology, queries Barthes (1975), if not "precisely the idea insofar as it dominates: ideology can only be dominant" (italics in original, p. 32). Counter-imagination functions as a transgressive reading practice only to 
the extent that it aids readers in creating their own Text, their own radical possibilities. ${ }^{7}$ What follows is our reading, our writing, of one futureoriented science fiction text, The Fifth Element, from the perspective of counter-imagination. ${ }^{8}$

\section{Reading the Future in The Fifth Element}

To illustrate the potential contribution of counter-imagination to the project of radical democracy, in this section we undertake a critical reading of the future in The Fifth Element. Conceived by director Luc Besson when he was only 16, the film's plot, typical of much sciencefiction fare, is set in motion by placing the world in eminent danger. The film concerns $23^{\text {rd }}$ century events, but it opens in 1914 in that metaphorical birthplace of civilizations, Egypt. In short, the present (the audience) is transported to a recognizable past (1914 Egypt) so that the future (the remainder of the film) will be perceived, not as a disconnected moment in time, but as a narrative movement with resonance, as a story with history. As two scientists excavate an ancient Egyptian site, they are interrupted by alien visitors known as the Mondoshawan who foretell the coming of evil in 300 years. Cut ahead to the year 2259, and an enormous fireball of absolute evil is hurtling toward the Earth to consume it. If the Earth is to be saved, reluctant antihero and $23^{\text {rd }}$ century New York cab driver, Major Korben Dallas (Bruce Willis), aided by Priest Vito Cornelius (Ian Holm) must locate four ancient stones representing earth, air, fire, and water along with a perfect being known as the fifth element (Milla Jovovich) and transport them to Egypt before the apocalyptic collision. As the Major and high priest race against time, they must also overcome the evil forces of a profit-driven madman, Zorg (Gary Oldman), and his alien minions, the Mangalores. To appreciate this story's contribution to social structures of inequality through collective imagination, however, we must look more closely at the unspoken assumptions and strategic silences that animate its representations.

\section{Of Alien Divas and Space Cowboys: Gender in The Fifth Element}

We would like to begin our analysis of Besson's gendered vision of the future with a brief discussion of the film's minor characters and overall visual artistry, as closer inspection reveals that these two aspects of the 
film are intricately interwoven. The audience's initial glimpse into the future, as constructed through the first several scenes of the film, forges a powerful, if unconscious, association between masculinity and social progress. As is typical of many science fiction films, social progress is defined principally as technological sophistication and excludes the "values associated with the feminine and with nature, which are often symbolically equated" (Rushing \& Frentz, 1994, p. 165). In the first thirty minutes of screen time, audiences are treated (and given the centrality of visual pleasure to this film, we mean "treated" not "introduced") to a landscape of endless technological marvels, advances enhanced by the film's stunning visual effects. For instance, after Leeloo (i.e., the fifth element) is seemingly killed when her spaceship crashes to Earth, a team of scientists "saves" her by completely reconstructing her from a single living cell. ${ }^{9}$ The rescue of Leeloo marks only the second appearance by a female character in nearly the first twenty minutes, and the other is by a speechless and androgynous presidential aid. The Fifth Element's introductory scenes virtually erase women from the realms of politics, religion, science, and the military-industrial complex. As the presidential aid illustrates (not to mention the "butch" Major Iceborg who appears later), a woman can only occupy these spheres by sacrificing her voice and her femininity. It is not until the narrative undertakes depictions of its servicebased economy that women begin to appear (i.e., be seen) in the film with regularity, and even then, their presence functions primarily to enhance the visually dazzling landscape. From Zorg's "ditsy" assistant to the drivethrough attendant at McDonald's and the interplanetary flight attendants, women are served up as "window dressing."

The Fifth Element strips its female characters of any human agency through a process Freud termed scopophilia, that is, by making them objects of a "controlling and curious gaze" (Mulvey, 1988b, p. 59). This is accomplished, in part, by dressing women in scantly clad apparel that accentuates their cleavage and employing camera framing that fragments their bodies and reinforces their status as passive objects. Observed popular film critic, Roger Ebert (1997), "the costumes are by French couturier Jean-Paul Gaultier, whose favorite strategy as a designer is to start by covering the strategic places, and then stop" (p. 33). In addition to being displayed as scenery for the audience's visual consumption, the film's female characters are also made the objects of the male gaze within the narrative. In the brief McDonald's scene, for example, a male police officer objectifies the female window attendant with his glance, and then 
demonstrates his power to direct the audience's gaze as well through the subsequent subjective camera shot of the woman's breasts. Hence, as Mulvey explains (1988b), "In their traditional exhibitionist role women are simultaneously looked at and displayed, with their appearance coded for strong visual and erotic impact so that they can be said to connote to-be-looked-at-ness" (italics in orginal, p. 62). The consistent and ubiquitous appeal to a collective vision of the future in which women serve predominantly as (sexual) objects normalizes a pattern of looking in the present in which masculinity is associated with agency (i.e., the power to direct the gaze) and objectification with pleasure.

Perhaps nowhere is this process of equating, indeed structurally infusing, the male gaze with pleasure more evident than during the concert scene aboard the futuristic cruise liner. Dallas and Leeloo have traveled to the liner to secure the ancient stones representing earth, air, water, and fire from a mysterious alien diva (Maiwenn Le Besco). In the diva's first screen appearance, she adorns a heavy cloak that obscures her features, fetishizing her exotic looks, and heightening the audience's desire to visually consume her. That evening when the diva takes center stage to give her operatic performance, Dallas sits utterly captivated in the audience-a vehicle for the theater audience's own captivation. In his review, Ebert (1997) describes the scene as a "great visual conceit ... starring a towering alien diva whose skin shines with ghostly blue light, and who has weird ropes of sinew coming out of her skull" (p. 33). The viewing audience is at this moment, continues Ebert, "watching 'The Fifth Element' not to think, but to be delighted" (p. 33). The film is, of course, silent about the way it creates delight, about its visual rape of the female form to create pleasure. The violence of the audience's gaze is suddenly and unexpectedly given image within the narrative as the alien diva is struck by gunfire and killed, thereby transferring the audience's violent actions onto the evil actions of the Mangalores. ${ }^{10}$ The violence inflicted by the aural and visual devouring of the diva is so great that it risks rupturing the filmic fantasy, and opening a space for self-reflective feelings of guilt. Since guilt would challenge the ideology of the gaze, however, the space is quickly closed through victimage."

The sheer dispensability of the alien diva is worthy of further reflection. A humanoid figure, the diva's blue skin is her primary marker of difference-a difference that is further exoticized by the complete absence of any other blue-skinned aliens in the film. The diva is unique and that uniqueness is, in turn, commodified-put on display for the voyeuristic 
pleasure of the cruise liner's passengers (and the film's viewers). It is acceptable, even encouraged, for the passengers and the theater audience to dominate the diva with their gaze precisely because she is different. Explains Kaplan (1997), "It is the oppressive structure of the objectifying gaze and the reliance on (superficial) exterior bodily signs (like skin color) that feed prejudice and hate" (italics in original, p. 299). Were the diva not alien - read racialized Other-would the violence of the gaze directed at her be tolerated? Would her death, which is forgotten by the other characters almost as quickly as it happens, be accepted and acceptable? The exoticizing of the alien diva highlights the racial invisibility of the film's primary characters, Leeloo and Dallas, who are both White. Their Whiteness is invisible to the other characters, to themselves, and not least of all to the audience. The diva's racial difference, then, is constructed in relation to the invisible norm of Whiteness, ${ }^{12}$ which unlike the alien diva is an indispensable category. Indeed, in a film strewn with violence, none of the White ethnic characters are killed.

Having examined several minor characters and their relation to the visual landscape, we now turn our attention to the film's two main characters, Leeloo and Korben Dallas. Leeloo, the fifth element, is the film's most complex character; she lies at its center, yet seems unable to exert any influence upon it. Narratively, Leeloo is vital to the Earth's salvation, but representationally she fares little better than the film's other female characters. Leeloo is introduced early in the film when she is literally given life by the hand of man. Articulating the "God-creator" perspective, the scientist who restores her body from a single cell gazes upon his completed work and deems it "perfect"-a sentiment reinforced by numerous male characters throughout the film. What is important here, however, is how "perfect" is defined. The audience's first view of Leeloo finds her naked in a glass cylinder-a sort of display case and iconic gesture to Sleeping Beauty. The audience's visual consumption of her body is immediately reinforced by the comment of the supervising officer, General Munro (Brion James), who declares, "I'd, uh, like to take a few pictures." Thus, within seconds of her screen appearance, Leeloo is, "woman as object of the combined gaze of spectator and all the male protagonists in the film" (Mulvey, 1988b, pp. 63-4). Moreover, her inability to speak English denies her the power of voice, a powerlessness that is symbolized by Munro's quip, "If you want out, you're going to have to learn to develop those communication skills." As one popular critic 
described her, Leeloo is "a near-nude nymph who speaks gibberish and has carrot-orange ringlets" (Wloszczyna, 1997, p. 13D).

The presence of the female figure poses an interesting paradox to films whose underlying structure exercises the male gaze, however. At the same time that women are vital as objects of the gaze, their presence signifies the threat of castration (in psychoanalytic terms, they noticeably lack the male phallus), which potentially undermines the pleasure created by their objectification. This paradox is generally resolved in one of two ways, either through extreme fetishization or the more sadistic mode of demystification. For most of the women in The Fifth Element, the former furnishes the preferred mode of resolution; the focus on physical beauty is so built up that all that survives is the looked-at-object, incapable of more complex narrative processes. In Mulvey's (1988b) words, "The beauty of the woman as object and the screen as space coalesce; she is ... a perfect product, whose body, stylized and fragmented by close-ups, is the content of the film and the direct recipient of the spectator's look" (p. 65). Although Leeloo, too, is displayed for visual enjoyment, it is not nearly so easy to disavow the castration threat she represents, especially not after she punches through the unbreakable glass in the science lab, "grabs the general's privates" (Ebert, 1997, p. 33), and escapes. In this mode, "pleasure lies in ascertaining guilt ... asserting control, and subjecting the guilty person through punishment or forgiveness" (Mulvey, 1988b, p. 64). As it turns out, Leeloo will ultimately be forgiven for her (phallic) incompleteness. To illustrate this development, we must introduce one additional level of complexity.

Narratives that feature females in leading roles would seem to offer some degree of agency for identification. After all, over the course of the narrative, Leeloo manages, despite her lack of voice, to single-handedly fight and defeat several Mangalores, and eventually acquire the ancient stones essential to saving Earth. As narrative resolution draws closer, however, Leeloo becomes ever more dependent on Dallas, and ultimately must be saved/supported by him to carry out the role that the beginning of the film suggested was uniquely hers. Early in the film, Leeloo exists in an almost childlike state represented by her extreme curiosity, innocence, and baby speak. She is experiencing, in Freudian terms, an active or phallic phase that all children, regardless of sex, undergo. As she matures over the course of the narrative, she becomes increasingly passive and dependent in her behavior. She is interiorizing patriarchal structures of femininity, which in Mulvey's (1988a) words, "leads to increasing repression of 'the 
active' " (p. 71). As the alien diva tells Dallas just before her death, "She's (Leeloo) more fragile than she looks. She needs your help and your love." . On the return trip to Earth with the sacred stones, Leeloo learns the horrors of humanity and becomes completely incapacitated by this knowledge, seemingly unable to carry out her role as the fifth element. The castration anxiety she evoked earlier is diminished through demystification, through an exploration of her femininity.

When our featured duo reaches Egypt, Dallas forgives her (phallic) incompleteness, supports her in his arms, and tells her that he loves her. It is at this juncture that the film's silent invitation for viewers to assume a patriarchal subject position is most fully realized. Although The Fifth Element never explicitly identifies what ("precious" element) Leeloo represents, the scene is structured to have the audience answer that question in a particular way. This scene, indeed the whole film, only makes sense (on its own terms) when the fifth element is understood by the audience to be love. Leeloo is only able to fulfill her capacity as the fifth element after she "gets her man." What the film never says, but the audience is implicitly encouraged to supply, is that Leeloo is now perfect because she has attained the love of Dallas. Please keep in mind that Leeloo is unable to complete her task before Dallas tells her that he loves her. Both narratively and visually, she needs his love to furnish her with the strength to unite the elements and ward off evil. Thus, the film's preferred subject position, despite its futuristic landscape, perpetuates the well-worn patriarchal idea that a woman needs a man to be complete.

Major Korben Dallas, the film's chief protagonist, functions both to - legitimize the male gaze and to provide a vehicle for the audience's consumption of the female form throughout the story. Coded as the typical space cowboy, Dallas represents strength and power, charm and ruggedness, and cunning and intelligence. Whereas the opening shots of Leeloo frame her naked body for visual consumption, Dallas is introduced with several close-up and medium shots of his face that position/define him as a subject with the ability to act. As Dallas begins his morning routine, the camera alternates between shots of his face and his numerous military awards, further inscribing his identity with power, prestige, and depth. In contrast to Leeloo, who arrives depthless and without history-a product (object) of (male) scientific ingenuity, Dallas enters with a past that testifies to his complexity, to his status as a subject. Within seconds of his introduction, Dallas' eventual acquisition of his most prized possession (Leeloo) is foretold in a phone conversation with his boss, Finger. 
DALLAS: (answering phone) Yeah?

FINGER: Hey bud! Finger here.

DALLAS: (his cat enters the room) Hi sweetie!

FINGER: I love you too Major, but you haven't called me that since basic training.

DALLAS: I was talking to the cat.

Fincer: Oh yeah, I forgot. You still prefer your cat to the real thing.

DALLAS: (looking at a picture of his wife) At least the cat comes back.

Finger: You still pining for that slut. Forget her. There are a million women out there.

DaLLAS: I don't want a million ... I just want one. A perfect one.

Finger's comment that, "There are a million women out there," denies women individuality, and reinforces the notion that women are merely objects to be consumed by men. By contrasting the "perfect one [woman]" with Dallas's wife (who demonstrated some degree of agency by leaving him), the phone conversation suggests that women who act are either imperfect or sluts-a term that simply re-interpolates them as objects. Thus, Leeloo's perfection hinges upon her consistent portrayal throughout the narrative as a passive object to be owned and controlled. By the narrative's end, Leeloo becomes Dallas's "mate" and, indeed, they are shown mating in the lab where Leeloo was (re)born. Thus, Dallas finds his "perfect one," who becomes his "perfect mate"-a highly sexualized and passive object.

After Leeloo escapes the scientific lab where she was created, she ends up in Dallas's cab. Once there, he immediately must rescue her from the police, an action he undertakes, it would seem, purely because of his desire to possess her. ${ }^{13}$ After all, he does not know her or what crime she is being pursued for (recall she lacks the voice to explain her situation), and his assistance implicates him as an accomplice. During the chase, Dallas deduces that she knows Vito Cornelius and decides to take her to his residence. He arrives at the priest's door with the now unconscious Leeloo limp in his arms, and Cornelius recognizes her as the fifth element. Leeloo's status as commodity is affirmed as Cornelius instructs Dallas, "Wake her up, but be gentle about it. This woman is mankind's most 
precious possession. She is ... perfect!" By envisioning a scenario in which the perfect woman can only exist as an object (possession of mankind), the film works to dissuade the audience from defining or envisioning female subjectivity in alternative terms. For Dallas and subsequently the audience, who is viewing the world through his eyes thanks to the liberal use of subjective camera shots from his point of view, Leeloo's perfection is defined entirely in terms of her beauty as an object. In a second phone conversation with Finger a short time later, Dallas explicitly links Leeloo's perfection with her beauty.

\section{DALLAS: (answering phone) Hello?}

FINGER: Hey bud! I'm waiting all day here [for you to show up].

DALLAS: Finger, man, I'm sorry. Listen. I was on my way over, but I had a fare fall into my lap. Y'know, one of those big fares you just can't resist.

FINGER: So just how big was this fare?

DaLLAS: 5'7", green eyes, long legs, great skin ... perfect.

By narrative's end, Leeloo will become the perfect object Dallas (and the audience) envisions by sacrificing her agency and submitting to his sexual desires. The final scene finds Dallas and Leeloo in the glass cylinder where she was created, and through the steamy glass the audience observes Dallas collect his trophy. The Fifth Element, then, appeals to a collective sense of the future in which the ability to control events and meanings coincides with the male protagonist's ability to, at once, substantively define the female form as object and formally activate the gaze through the direction of camera framing and editing. "The male protagonist is free to command the stage," notes Mulvey (1988b), "a stage of spatial illusion in which he articulates the look and creates the action" (p. 63).

The construction of sexual difference along the axes of technology and nature, subject and object, looker and looked at, and protector and protected do not tell the whole story of how The Fifth Element envisions subjectivity, however. Dallas's masculinity, not to mention his status as narrative hero, is as much a product of his relation to the other male characters as it is to Leeloo. Dallas projects/embodies the 'ideal' of masculinity, at least in part, by the manner in which the other male characters are differentiated from him. Interestingly, many of the film's 
other central male characters are racialized, or in the case of Rudy Rhod racialized and feminized, in relation to Dallas, who representationally occupies a silent and centered norm.

\section{Of Powerless Beasts and Flaming Beauties: Race in The Fifth Element}

The future envisioned in The Fifth Element is, like many science fiction tales, populated by tremendous diversity, both ethnic and speciel. The outward appearance of multiculturalism is hardly surprising given that, as Evans explains, "The heart and soul of science fiction, and to some extent, fantasy, has always been the encounter with the 'other', with 'difference' " (quoted in Porter, 2002, p. 5L). But precisely what Other(ing) messages are communicated by the (re)presentations of racial difference within appeals to popular imagination? In addressing this question, we combine Xing's (1998) tri-part framework regarding, "racist practices in casting as a particularly important dimension of the racism embedded in institutional representation: role segregation, role stratification, and role delimitation" (p. 74) with critical textual analysis of the character representations in The Fifth Element. This analysis indicates that the film's portrayal of racial difference functions ideologically to perpetuate ethnic stereotypes and stigmatize ethnic voice and identity while simultaneously co-opting ethnic images in an apparent celebration of diversity and multiculturalism.

According to Xing (1998), "[s]egregating actors by roles seems to be reasonable, sometimes even desirable when ethnic characters are cast. But the major problem is not role segregation per se, but the double standards used in casting" (p. 74). Whereas Hollywood casting practices frequently allow White ethnic actors to permeate ethnic identity boundaries and to play characters of varying ethnic heritages, ethnic minority actors are denied the same opportunities to cross role/identity boundaries. In The Fifth Element, this inequity is evident not only in the casting of the film's central heroic characters (who are, of course, all played by White actors), but also in the casting of White actors to play key non-White ethnic characters. ${ }^{14}$ In the section that follows, we offer the character of JeanBaptiste Emmanuel Zorg-played by actor Gary Oldman-as a prototypical example of the cinematic ethnic makeover. We then examine a second character, President Lindberg (Tom 'Tiny' Lister, Jr.), and consider how the casting and representation of this role participates in the politics of identity. 
Gary Oldman is a well-known and respected White actor in U.S. American filmmaking. For his role as Zorg in The Fifth Element, however, his White ethnic identity is largely erased by projecting a more Asian image onto him. Oldman's Asian-ness is not simply a crude stereotype though, as it also incorporates what is perhaps best characterized as a broken Southern accent. In the introduction to this essay, we noted that one of the unique features of science-fiction films is that they allow for experimentation with identities, be they gender or ethnic identities. Oldman's ethnic makeover, then, offers a futuristic, hybridized identity, in which his Asian appearance is subtle, but nonetheless marks him as ethnically different from the other main characters. Zorg's unilength, shiny-black hair, "accessorized by what looks like a windshield" (Wloszczyna, 1997, p. 13D), offers a twenty-third century update on the stereotypical Asian bowl haircut. Dressed in iridescent shirts and Italiancut suits tailored with dramatic style, Oldman is transformed into a partially Southern, partially Asian, partially Italian, but decidedly 'ethnic' character. Ethnicity is defined not by a single, unified stereotype, but by the fact that Zorg sounds, looks, and dresses different than the film's other main (White) characters. Hence, even as the film rejects the use of crass racial stereotypes in this instance, ethnic difference continues to be constructed in relation to Whiteness--"the omnipresent center, the invisible center which claims universality without ever defining itself, and which exiles to its margins those who cannot or will not pay allegiance to the standards which it sets or the limits which it imposes" (Ferguson, 1990, p. 13).

The implications of the Oldman transformation are also significant for what the "sinister Zorg" (Ebert, 1997, p. 33) says about the ethnic Other. As the film's chief antagonist, Zorg is the primary signifier of evil. From the outset, viewers are invited to disassociate with Oldman's character, who is portrayed as a compassionless warmonger and money-hungry madman. The audience is, in short, encouraged to adopt a subject position that is anti-Zorg and to root for his defeat and eventual destruction. Given the centrality of 'ethnicity' to the character of Zorg, anti-Zorg sentiment is closely tied to cultural attachment away from Zorg as a White ethnic agent and toward a more pronounced read of Zorg as an evil Asian ethnic agent. The simultaneous erasure of Zorg's White ethnic identity and his coding as evil severely undercuts the progressiveness of the film's futuristic race politics. The White male actor continues to occupy a central character role, but the negative images associated with the role become largely disasso- 
ciated with White ethnic identity and are (re)cast not only as the evil agent, but also as an ethnic identity that subtly demonizes Asian-ness in the process.

Moving from problems of role separation to problems with power and competence of roles, Xing (1998) writes:

Eugene Wong calls role stratification the vertical counterpart to role segregation in the racial politics of casting. While Asian actors and actresses [ethnic minorities] are often cast primarily as background fillers and to create cinematic atmosphere as extras and 'racials,' he claims they are not considered competent enough to play leading roles. (p. 76)

Such stratification is clear in The Fifth Element, which casts numerous non-White actors in minor, background roles. For instance, the vast majority of Zorg's subordinates in the film are visibly of non-White ethnic backgrounds. The result is a vision of the future that, upon first glance, appears to be highly multicultural. The fact that ethnic diversity is limited primarily to minor roles-which are themselves for subordinate characters (e.g., characters who sheepishly take orders), however, militates against the film's seemingly progressive racial politics. The one notable exception to this general casting practice is the casting of actor Tom 'Tiny' Lister, Jr. in the role of President Lindberg. Depicting a future in which a Black man is President contributes to the film's outward celebration of diversity and offers a potentially progressive subject position. In evaluating the film's deep ideological structures regarding identity politics though, it is vital to examine how the role of the President is represented within the narrative.

"[Director Luc] Besson breaks ground by having a black man, the imposing Tiny Lister, Jr., as the president," writes USA Today film critic Susan Wloszczyna (1997), "although the president of what, I'm not quite sure" (p. 13D). The Fifth Element is unclear about what, if any, nation states or political divisions exist in the twenty-third century, and the subsequent ambiguity surrounding precisely what the President governs functions to undercut viewers' perceptions of his power despite his ostensibly important political position. The issue of his power (or lack thereof) is placed in still further doubt by the manner in which the President is represented in his interactions with other characters. Throughout the film, the President is consistently depicted as a leader whose discourse and actions are characterized more by uncertainty and worry than by confi- 
dence and calm. The film's original script (1995, August), for instance, notes the leadership style of the President with the following stage directions: "worried ... exasperated. ... The President hesitates. ... The President is growing even more worried. ... The President looks puzzled" (n.p.). During the course of one of the film's key crisis scenes, the President's discourse highlights his relative ineffectualness:

President: Your theory is interesting Father, but we don't have time to go into that right now!

Father CoRnelius: Time is of no importance, Mr. President. Only life is important.

PRESIDENT: (exasperated) You're right, that's exactly what we're gonna do: We're gonna protect life of some 200 billion of my fellow citizens! General? You may fire when ready.

General Staedert: (cold) (to the captain).... Up front loading of a 120 ZZR missile. Marker lights on the objective.

SCIENTIST 1: (consulting new data) Its structure has just solidified on the surface.

SCIENTIST 2: I think it's anticipating the attack. Anticipation denotes intelligence.

CoRnelius: The most terrible intelligence imaginable, $\mathrm{Mr}$. President.

(The President hesitates).

General Staedert: The ship is in combat formation. Missiles are loaded, Mr. President.

PRESIDENT: (uneasy) Staedert? Give me a minute... I have a doubt.

General Staedert: (cold) I don't, Mr. President.

(The missile explodes from the ship and penetrates its target. The explosion is swallowed like a fizzy pill in a small glass of water. Nothing happens. And then the mass grows larger).

As this-the most prominent scene involving President Lindberg-suggests, the character played by Lister is an important one to the underlying identity politics of the film. The audience is invited to imagine a future in which a Black man is the agent of Presidential power, an apparent challenge to role stratification. But narratively, the character demonstrates no ability to restore order, resolve crises, or influence events. Although Lister has a booming voice and an imposing presence, the discourse and 
actions of his character are uncertain, unproductive, and un-heroic. By contrast, Willis's character, Korben Dallas, becomes the central locus of power, not because his character role (as a taxi driver) necessitates it, but because his (stereotypically masculine) actions demonstrate it. The film is, of course, silent about these associations and before the audience can become too critical of the flailing leadership of this 'Black' President, the action is interrupted by a spectacular explosion-a distraction that moves the audience away from social critique and into the realm of sensory delight.

"Role delimitation" (Xing, 1998, pp. 77-78) provides the final lens through which we assess racial constructions in The Fifth Element. Delimitation concerns the complexity of roles that may be occupied by actors, and more specifically, by non-White actors. Asserts Mercer (1999),

Mass media stereotypes of black men-as criminals, athletes, entertainers-bear witness to the contemporary repetition of such colonial fantasy, in that the rigid and limited grid of representations through which black male subjects become publicly visible continues to reproduce certain idées fixes, ideological fictions and psychic fixations, about the nature of black sexuality and the 'otherness' it is constructed to embody. (Italics in original, p. 437)

Perpetuating the stereotypical Black role of entertainer noted above, actor Chris Tucker's character Ruby Rhod (read as: feminized first name with a phallic surname) provides a multi-layered gender-bending, sexually flaming, Black character for critical analysis.

"Besson gives us one great visual conceit after another," writes Ebert (1997), "[such as a] space station that seems to be a sort of intergalactic Las Vegas, in which a disc jockey (Chris Tucker) prances about hosting an endless TV show" (p. 33). There is little doubt that the high volume, high energy, hypersexual Ruby Rhod is offered as pure sensory delight for the audience. He is among the film's most dazzling visual effects-a grand spectacle. Ruby's role as an object of entertainment is, like the alien diva, rooted in his cultural difference--difference that, in this case, is tied to the complex intersection of race and sexuality. On the one hand, Ruby Rhod is coded as the stereotypical "flaming beauty," complete with make-up, effeminate gestures, high-pitched voice, and cross-dressing fashion. On the other hand, he activates what Byrd (1998) terms, "the black buck 
mythic type" (p. 77), with his sexual conquest of a random female flight attendant aboard an intergalactic spaceship en route to Fhloston Paradise (lost in paradise). The coding of Ruby as "gay" distinguishes him from the more stereotypically austere, masculine, and heterosexual Space Cowboy Korben Dallas, and makes Ruby's sexuality exotic-a fascination. At the same time, the film is careful not to make Ruby "too gay," a move that in his interactions with Korben Dallas might 'problematize' Korben's sexuality. In characterizing Ruby as, at once, gay and not too gay, the film offers a carnival of 'sexual exoticism' for the audience that is 'safe' (e.g., the audience can enjoy Ruby without adopting a pro-gay subject position), but nevertheless reaffirms heterosexual masculinity as the silent norm.

The juxtaposition of Space Cowboy and Flaming Beauty, which is also the juxtaposition of White and Black and masculine and feminine, is most pronounced in the scenes where the two characters first meet and then work to escape from the evil forces of Zorg and the Mangalores. Upon their meeting, Ruby Rhod "comes out" to greet Korben in a leopard print, skin tight, body suit. With dramatic flair, Ruby seductively prowls toward Korben and exclaims, "This boy is fueled like fire, so start melting ladies because the boy is hotter than hot. He's hot, hot, hot!" In commenting on Korben's machismo, Ruby's discourse initially charges their relationship with sexual tension-a tension that is partially displaced by Ruby's earlier (hetero)sexual conquest. As the action continues, Ruby's interaction with Korben becomes increasingly tied to the "hero" story. During the lifethreatening, action-packed scenes, Ruby panics and screams for Korben to save him, playing the stereotypical "drama queen" or "damsel in distress" role. For Ruby, Korben has shifted from object of desire to savior. But what is it about their respective identities that positions Ruby as "needing saved" and Korben as "savior"? Through visual contrast, the film suggests that the answer is their racial and sexual(ity) identities. As it turns out, the issue of sexuality is really about gender. Korben must rescue Ruby not because Ruby is homosexual, as the narrative suggests that he is not really gay. He must rescue Ruby because he is weak and helpless-traits which are signified by his effeminacy. This ideology reinforces the historical stigmatization of gays, not for their choice of sexual partners, but for their "woman-like" character (see Chauncey, 1994, p. 13). Ruby's relational and narrative subordination to Korben, once again, privileges masculinity and more specifically, White heterosexual masculinity, as the locus of heroism.

With regard to the role delimitation of other characters, Zorg's interaction with Aknot, leader of the Mangalores-"whose faces can be pic- 
tured by crossing a bulldog, a catfish, and an alderman" (Ebert, 1997, p. 33) - provides another example of the film's racial politics working to perpetuate negative stereotypes of Black identity. In the scene where Zorg and Aknot meet to negotiate the $\mathrm{ZFl}$ weapon, the following interaction takes place:

ZORG: (pretending to be worried) Aknot? Is that you?

(The Leader nods. A disgusted look stamps Zorg's features.)

ZORG: . . . What an ugly face! It doesn't suit you! Take it off. . .

(Aknot's face burns away revealing the head of a monstrous

Mangalore.)

ZoRG: That's better! Never be ashamed of who you are...

You're warriors ... . be proud. ...

(Aknot says nothing)

With the use of digital special effects, the face of Aknot is magically transformed from a Black man to a Mangalore-a sort of twenty-third century troglodyte. Although Zorg's comment to "never be ashamed of who you are" appears to be a benign cliché, the visuals accompanying this statement suggest that who the Black man Aknot really is, is an animalistic beast.

Finally, in two short scenes, the audience encounters two other stereotypical characters that exemplify the essentialist trap that ethnic minorities face with regard to role delimitation. In one early scene, Korben interacts with an older Asian sage-_"You got a message. Not going to open it? Could be important." This brief scene is visually quite telling regarding the politics of identity. Despite the futuristic looking space cars that zip through the air like a well-conducted ballet, the Asian character maneuvers his slower, exhaust polluting, "Fortune for you" boat-ship near Korben's residence. This water-like, floating boat-ship complete with Asian lanterns and hanging glazed ducks is distinctly less aerodynamic than the other (space)ships flying along the postmodern landscape. In fact, amidst the sleek and fast paced new order of transportation technology, the Asian food vendor and his boat read like a twenty-first century "Third World" in the twenty-third century. In another much later scene, a similar stereotyping occurs. With the main characters boarding an intergalactic spaceship, the camera pans to a maintenance worker, who with Jamaican rhythmic voice grooves to Reggae music as he works the deck. In that brief moment, the audience is invited to experience a quick comedic escape by a 
dreadlocks wearing, 'Rasta Reefer,' whose presence, like so many other minor characters in the film, continues to go "up in smoke."

\section{Counter-Imagination and Critical Pedagogy}

Criticism can, of course, be undertaken for a host of different purposes, ranging from artistic and analytical to ideological and pedagogical (see Warnick, 1992, p. 232). In writing an essay about The Fifth Element, our purposes tended toward the latter of these. "If we regard ordinary people (students) as the primary audience for rhetorical theory and its criticisms," as Brummett (1984b) advocates, "then rhetorical theory and criticism's ultimate goal and justification is pedagogical: to teach people how to experience their rhetorical environments more richly" (italics in original, p. 103). As educators, our purpose was twofold. On the one hand, we wanted to demonstrate to our students that films, no matter how fantastic and carnivalesque, have the potential to limit our vision of our world and ourselves. "Whether we like it or not," explains hooks (1996), "cinema assumes a pedagogical role in the lives of many people. It may not be the intent of a filmmaker to teach audiences anything, but that does not mean that lessons are not learned. ... my students learned more about race, sex, and class from movies than from all the theoretical literature I was urging them to read" (p. 2). Our analysis of The Fifth Element suggests that such lessons can be particularly violent ones about voice, subjectivity, and social relationships. On the other hand, we wanted to help students realize that they, as active and oppositional readers, have the ability to unmake the ideology of a film. Thus, we set out to sketch the contours of an interpretive practice for deconstructing the deep ideological structures in one particularly compelling mode of popular entertainment, the future-oriented science fiction film. In closing, we reflect both on the specific contributions of counter-imagination as a reading practice as well as on the ways it might be incorporated into a broader critical pedagogy.

With film and other mass mediated forms playing such an important role in shaping how we view ourselves and our world outside of the classroom, popular culture provides a rich resource and terrain for learning about the intersection of identity, power, and politics in the classroom. "When we desire to decolonize minds and imaginations," notes hooks (1994a), "popular culture... [offers] a powerful site for intervention, challenge, and change" (p. 5) by providing "a shared experience, a common starting point from which diverse audiences can dialogue about 
... [the] charged issues [of race, gender, sexuality, and class]" (hooks, 1996, p. 2). The key to using film and other popular cultural texts as effective educational tools is getting students to move beyond simple aesthetic judgments and into the realm of critical evaluation. Unless students are taught to engage media texts critically, they are likely simply to adopt the "preferred" subject positions encouraged by a text and thereby to reproduce existing hegemonic social structures. Reading critically, however, requires oppositional codes (Hall, 1993, p. 103; Steiner, 1988, pp. 13-4), and access to oppositional codes is often limited (Condit, 1989, p. 103). Thus, cultural scholars and teachers must continuously work to chart the ways that various forms and genres of media texts function ideologically (see especially hooks, 1994b). In equipping historically marginalized subjects with decoding strategies that legitimate and empower their voices and identities, we can begin to foster more democratic social forms.

Our aim in playing with the notion of counter-imagination has been to contribute one small piece to that very large puzzle, to illustrate an interpretive practice for reading future-oriented science fiction in a counter-hegemonic way. Counter-imagination concerns how, through futuristic images, appeals to popular imagination inform, shape, and structure configurations of power in the present. It does this by attending to the distortions of beings and landscapes in images of the future, and the manner in which those distortions normalize and naturalize social relations and systems in the present. The Fifth Element, for instance, presents audiences with a futuristic landscape marked by endless technological marvels and pure sensory delights. But it (re)presents that landscape in a manner that codes technological progress as masculine and active and simultaneously relegates the female form to background decoration, a mere fetishized object of visual pleasure. It begins narratively with the depiction of a central and vital female character and slowly strips her of her agency, preferring to find heroism, strength, and independence in the category of masculinity. It paints a portrait of the future filled with racial diversity, but continues to privilege White heterosexual masculinity, to promote racial tourism and tokenism, and to renew existing social structures of inequality in the guise of multiculturalism and social progress. The Fifth Element-with its futuristic characterizations of the "fragile, sexualized Perfect-being," "exoticized alien diva," "rugged space cowboy," "Black President," "hybridized Asian-White male," and "flamboyant 
Black male"-invites viewers to collectively imagine a reified present as the vision of a "progressive" future.

Even when viewers possess oppositional codes such as counter-imagination in their reading repertoires, putting a critical pedagogy into practice is not absent its difficulties. There is, for instance, the additional challenge of the pleasure that comes from conforming to the dominant code-of accepting ready-made meanings. Barthes (1975) terms this pleasure plaisir and notes that it "is linked to a comfortable practice of reading" (italics in original, p. 14). Because pleasure (specifically plaisir) is readily available in "conforming to the dominant ideology and the subjectivity it proposes" (Fiske, 1989, p. 54; see also Fiske, 1987, p. 228), students frequently share with us that they choose not to read oppositionally, not because they lack the codes to do so, but because they believe it destroys the pleasure of viewing. On one level, they are correct, and, in fact, Condit (1989) identifies "the ratio between the work required and pleasure produced in decoding a text" as a significant reason why viewers do not read oppositionally (p. 103). Although reading oppositionally, or reading against the grain, destroys plaisir (see Mulvey, 1988b, p. 59), it does not necessarily have to be work. It can be its own mode of pleasure. Students need to be taught that pleasure and criticism can coexist. ${ }^{15}$ Jouissance is, for Barthes (1975), the pleasure of evading the social order and the forces that subjugate (p. 14). It is the pleasure that comes from creating one's own Text from the resources of the dominant culture, of reading to create new, liberated subjectivities, and of escaping the disciplining structures of society (Barthes, 1985, pp. 173-4; Barthes, 1988a, p. 164; Fiske, 1987, p. 229; Fiske, 1989, p. 51).

In the context of looking at science fiction films, we believe the pleasure of jouissance can be experienced in the interpretive practice of counter-imagination. Counter-imagination questions the ready-made subjectivities that are popularly constructed in future-oriented science fiction films like The Fifth Element. By adopting this practice, we believe that students can begin to appreciate and legitimate voices and identities that lie outside the "preferred" and "privileged" subject positions that films too often invite. As students begin to adopt subversive stances to the "preferred" subject positions, they will also begin to envision a world no longer constrained by oppressive cultural codes. With a future whose possibilities are limited only by our imagination, counter-imagination is one tool for students who seek to understand their subjectivities and to 
create new ones. It is, in short, a tool for envisioning and building a future of radical possibility.

\section{References}

Aronowitz, S. \& Giroux, H. (1991). Postmodern education: Politics, culture and social criticism. Minneapolis: University of Minnesota Press.

Barthes, R. (1973/1975). The pleasure of the text (R. Miller, Trans.). New York: Hill and Wang.

Barthes, R. (1981/1985). The adjective is the "statement" of desire. In L. Coverdale (Trans.), The grain of the voice: Interviews 1962-1980 (pp. 172-176). Berkeley: University of California Press.

Barthes, R. (1977/1988a). From work to text. In S. Heath (Trans.), Image, music, text (pp. 155-164). New York: Noonday Press.

Barthes, R. (1977/1988b). The death of the author. In S. Heath (Trans.), Image, music, text (pp. 142-148). New York: Noonday Press.

Barthes, R. (1984/1989). Writers, intellectuals, teachers. In R. Howard (Trans.), The Rustle of Language (pp. 309-331). Berkeley: University of California Press.

Benson, T. (1998). Thinking through film: Hollywood remembers the blacklist. In J. M. Hogan (Ed.), Rhetoric and community: Studies in unity and fragmentation (pp. 217-255). Columbia: University of South Carolina Press.

Benson, T., \& Anderson, C. (1989). Reality fictions: The films of Frederick Wiseman. Carbondale: Southern Illinois University Press.

Blair, C., Jeppeson, M., \& Pucci, E. (1991). Public memorializing in postmodernity: The Vietnam Veterans Memorial as prototype. Quarterly. Journal of Speech, 77, 263288.

Bodnar, J. (1992). Remaking America: Public memory, commemoration, and patriotism in the twentieth century. Princeton: Princeton University Press.

Browne, S. (1995). Reading, rhetoric, and the texture of public memory. Quarterly Journal of Speech, 81, 237-265.

Brummett, B. (1984a). Burkean comedy and tragedy, illustrated in reactions to the arrest of John DeLorean. Central States Speech Journal, 35, 217-227.

Brummett, B. (1984b). Rhetorical theory as heuristic and moral: A pedagogical justification. Communication Education, 33, 97-107.

Brummett, B. (1994). Rhetoric in popular culture. New York: St. Martin's Press.

Byrd, M. L. (1998). Multicultural communication and popular culture: Racial and ethnic images in Star Trek. New York: McGraw-Hill

Chauncey, G. (1994). Gay New York: Gender, urban culture, and the making of the gay male world, 1890-1940. New York: Basic Books.

Condit, C. (1989). The rhetorical limits of polysemy. Critical Studies in Mass Communication, 6, 103-122.

Croteau, D., \& Hoynes, W. (2000). Media/Society: Industries, images, and audiences $\left(2^{\text {nd }}\right.$ ed.). Thousand Oaks, CA: Pine Forge Press.

Cuomo, C., \& Hall, K. (1999). Introduction: Reflections on whiteness. In C. Cuomo \& K. Hall (Eds.), Whiteness: Feminist Philosophical Reflections (pp. 1-12). New York: Rowman \& Littlefield.

Dyer, R. (1997). White. New York: Routledge.

Ebert, R. (1997, May 9). Wonders to behold; Magnificent 'Element' puts faith in effects. Chicago Sun-Times, p. 33.

Ferguson, R. (1990). Introduction: Invisible center. In R. Ferguson, M. Gever, T. 
Minh-ha, \& C. West (Eds.), Out there: Marginalization and contemporary culture (pp. 9-14). Cambridge, MA: The MIT Press.

Fiske, J. (1987). Television culture. New York: Routledge.

Fiske, J. (1989). Understanding popular culture. Boston: Unwin Hyman.

Hall, S. (1993). Encoding/Decoding. In S. During (Ed.), The cultural studies reader (pp. 90-103). New York: Routledge.

Haraway, D. (1991). Simians, cyborgs, and women: The reinvention of nature. New York: Routledge.

hooks, b. (1989). Talking back. Boston: South End Press.

hooks, b. (1994a). Outlaw culture: Resisting representations. New York: Routledge.

hooks, b. (1994b). Teaching to transgress: Education as the practice of freedom. New York: Routledge.

hooks, b. (1996). Reel to real: Race, sex and class at the movies. New York: Routledge. Jameson, F. (1982). Progress versus utopia; or, can we imagine the future? Science Fiction Studies, 9, 147-158.

Johnson, P. (1999). Reflections on critical white(ness) studies. In T. Nakayama \& J. Martin (Eds.), Whiteness: The communication of social identity (pp. 1-7). Thousand Oaks: Sage.

Kaplan, E. A. (1997). Looking for the other: Feminism, film, and the imperial gaze. New York: Routledge.

Ledoux, P. (Producer), \& Besson, L. (Writer/Director). (1997). The Fifth Element [Motion picture]. United States: Columbia Pictures.

Loshitzky, Y. (Ed.). (1997). Spielberg's holocaust: Critical perspectives on Schindler's List. Bloomington: Indiana University Press.

McGee, M. (1984). Another philippic: Notes on the ideological turn in criticism. Central States Speech Journal, 35, 43-50.

McGee, M. (1990). Text, context, and the fragmentation of contemporary culture. Western Journal of Speech Communication, 54, 274-289.

Medhurst, M. (1993). The rhetorical structure of Oliver Stone's JFK. Critical Studies in Mass Communication, 10, 128-143.

Mercer, K. (1999). Reading racial fetishism: The photographs of Robert Mapplethorpe.

- In J. Evans \& S. Hall (Eds.), Visual culture: The reader (pp. 435-447). London: Sage.

Mulvey, L. (1988a). Afterthoughts on "visual pleasure and narrative cinema" inspired by Duel in the Sun. In C. Penley (Ed.), Feminism and film theory (pp. 69-79). New York: Routledge.

Mulvey, L. (1988b). Visual pleasure and narrative cinema. In C. Penley (Ed.), Feminism and film theory (pp. 57-68). New York: Routledge.

Nakayama, T. (1994). Show/down time: "Race," gender, sexuality, and popular culture. Critical Studies in Mass Communication, 11, 162-179.

Nakayama, T., \& Krizek, R. (1995). Whiteness: A strategic rhetoric. Quarterly Journal of Speech, 81, 291-309.

Ott, B., \& Aoki, E. (2001). Popular imagination and identity politics: Reading the future in Star Trek: The Next Generation. Western Journal of Communication, 65, 392-415.

Penley, C. (1991). Introduction. In C. Penley, E. Lyon, L. Spigel, \& J. Bergstrom (Eds.), Close encounters: Film, feminism, and science fiction (pp. vii-xi). Minneapolis: University of Minnesota Press.

Pierre, N. (1989). Between memory and history: Les Lieux de mémoire. Representations, 26, 13-25. 
Porter, W. (2002, February 17). Afro-American sci-fi writers have a mentor: Butler among trendsetters. The Denver Post, pp. $1 \mathrm{~L}, 5 \mathrm{~L}$.

Rushing, J., \& Frentz, T. (1994). The Frankenstein myth in contemporary cinema. In W. Nothstine, C. Blair, \& G. Copeland (Eds.), Critical questions: Invention, creativity, and the criticism of discourse and media (pp. 161-182). New York: St. Martin's Press.

Scholes, R. (1975). Structural fabulation: An essay on fiction of the future. Notre Dame, IN: University of Notre Dame Press.

Shugart, H. (1997). Counterhegemonic acts: Appropriation as a feminist rhetorical strategy. Quarterly Journal of Speech, 83, 210-229.

Simon, R. (1994). Forms of insurgency in the production of popular memories: The Columbus quincentenary and the pedagogy of countercommemoration. In $\mathrm{H}$. Giroux \& P. McLaren (Eds.), Between borders: Pedagogy and the politics of cultural studies (pp. 127-142). New York: Routledge.

Steiner, L. (1988). Oppositional decoding as an act of resistance. Critical Studies in Mass Communication, 5, 1-15.

Thompson, J. (2002, July). Star wars: Telling it like it is. The Rocky Mountain Bullhorn, p. 19.

Warnick, B. (1992). Leff in context: What is the critic's role? Quarterly Journal of Speech, 78, 232-237.

Wloszczyna, S. (1997, May 9). 'Element': A garish romp into the future. USA Today, p. 13D.

Xing, J. (1998). Asian America through the lens: History, representations and identity. Walnut Creek, CA: AltaMira Press.

Young, J. (1993). The texture of memory: Holocaust memorials and meaning. New Haven: Yale University Press.

Zelizer, B. (1992). Covering the body: The Kennedy assassination, the media, and the shaping of collective memory. Chicago: University of Chicago Press.

Zelizer, B. (1995). Reading the past against the grain: The shape of memory studies. Critical Studies in Mass Communication, 12, 214-239.

\section{Notes}

'Among recent treatments of the politics of collective memory, see especially Pierre (1989), Bodnar (1992), Young (1993), Simon (1994), and Blair, Jeppeson, and Pucci (1991). For an overview of the literature on public memory in rhetorical studies, see Browne (1995).

${ }^{2}$ Benson (1998) examines how Robert DeNiro's film Guilty by Suspicion constructs public moral memory regarding the Hollywood blacklist. Zelizer (1992) analyzes Oliver Stones' film $J F K$ in the context of other mediated texts as a means of demonstrating how collective memory of the Kennedy Assassination has been shaped over the past 30 years, while Medhurst (1993) offers a detailed analysis of the film's rhetorical structure. Loshitzky (1997) provides a collection of essays that explore the ways in which Spielberg's Schindler's List invites audiences to remember the Holocaust. For an overview of the literature on public memory in media studies, see Zelizer (1995).

${ }^{3}$ One particularly provocative engagement with science fiction is the work of Donna Haraway (1991), which draws on cyborg imagery to outline a new vision for socialist-feminism in the late twentieth century. It is worth noting that the image of the cyborg is not inherently progressive, but that Haraway (re)codes it to serve that purpose.

${ }^{4}$ Three extremely helpful essays on oppositional reading are Steiner's (1988) "Oppositional decoding as an act of resistance," Condit's (1989) "The rhetorical limits 
of polysemy," and hooks' (1996) "The oppositional gaze: Black female spectatorship" in Reel to Real.

${ }^{5}$ We understand a radical democracy to embody a set of social relations free from social structures that function to sustain inequality, oppression, and injustice based on culturally constructed notions of difference (see Aronowitz \& Giroux, 1991).

${ }^{6}$ We are offering "counter-imagination" as a mode of interpretive resistance. It is a set of oppositional codes and a reading practice used by audiences to "resist the imposition of meaning and [to] construct new readings that stand in political opposition to the preferred meanings [and dominant ideologies]" (Croteau \& Hoynes, 2000, p. 286) of future-oriented science fiction. This reading practice is counter-hegemonic in the same general sense that "oppositional decoding" is in Hall (1993), Steiner (1988), and Nakayama (1994). We are not using counter-imagination to refer to oppositional or counter-hegemonic codes in the same sense that Shugart (1997) uses those concepts, however. She is concerned with describing how texts (the film Shane and the Margaret Atwood poems "Orpheus (1)" and "Eurydice") are structured to challenge dominant ideologies by examining the codes, such as appropriation, that submerged groups employ to produce those texts. So, whereas Shugart is charting the characteristics of counter-hegemonic texts, we are highlighting an interpretive practice for reading hegemonic texts, such as The Fifth Element, in a counter-hegemonic way.

${ }^{7} \mathrm{We}$ are using "Text" here in the Bartesian sense of the word (see Barthes, 1988a). When citizens (students) read media artifacts uncritically (dominantly or preferred), they are preserving the entire ideological apparatus of the Author-this is not a reference to the specific author (i.e., media producer) of the artifact, but to the broader cultural structures of authorship-and hence treating the artifact as a finished whole, as a "Work." This is the very reading practice that reproduces dominant ideology and subject positions. Reading oppositionally, by contrast, does not respect the whole. It opens the "Work" to contradictory codes and transforms it into a living "Text." With counterimagination, we are offering a perspective to similarly transform future-oriented SF "Works" into "Texts."

${ }^{8} \mathrm{We}$ are in agreement with McGee (1984) that "preoccupation with procedure leads to the virtual equation of 'method' with what should be conceived as its opposite, the idea of 'perspective" " (italics in original, p. 47). Likewise, we are in agreement with Barthes (1989) that there is "no surer way to kill a piece of research and send it to join the great scrap heap of abandoned projects than Method" (p. 318). As with "Ideologiekritik," counter-imagination, "is in fact not a method, but a practice" (italics in original; McGee, p. 49). It supplies the attitude for reading future-oriented science fiction, but strives not to prescribe or enforce a singular approach.

${ }^{9}$ As the fifth element, Leeloo is central to saving Earth. But despite this important role, technology (coded principally as masculine) masters nature by saving Leeloo's life (coded principally as feminine).

${ }^{10}$ The Mangalores shoot and kill the alien diva to prevent her from telling Dallas where the sacred stones are located. As it turns out, the stones are inside her body and Dallas removes them as she is dying.

"For an excellent discussion of victimage as a symbolic device for resolving guilt, see Brummett (1984a).

${ }^{12}$ The "invisibility" of Whiteness is significant because, as Dyer (1997) explains, "As long as race is something only applied to non-white peoples, as long as white people are not racially seen and named, they/we function as a human norm. Other people are raced, we are just people" (p. 1). The aim of making Whiteness visible is both pedagogical and political (see Nakayama and Krizek, 1995, pp. 293-4; Cuomo and Hall, 1999 , p. 3). By interrogating the "subjectivity and particularism" of Whiteness, we hope 
like Johnson (1999), "[to] create new intellectual space for relational understanding and, more important, racial justice" (p. 5).

${ }^{13}$ Dallas's actions as a subject and his visual consumption of Leeloo function as mutually reinforcing modes of pleasure. "As the spectator identifies with the main male protagonist, he projects his look on to that of his like, his screen surrogate, so that the power of the male protagonist as he controls events coincides with the active power of the erotic look, both giving a satisfying sense of omnipotence" (Mulvey, 1988b, p. 63).

${ }^{14}$ We recognize that the term "non-White," as Dyer (1997) notes, "is problematic because of its negativity, as if people who are not white only have identity by virtue of what they are not" (p. 11). Lacking a better term to describe contemporary social structures that participate in a center/margin discourse, we, like Dyer, reluctantly use the term.

${ }^{15}$ Since it is the very practice (act) of reading oppositionally that creates new, liberated subjectivities, it is vital that students read oppositionally. Thus, the reason we have suggested how it is linked to pleasure at the end of our essay is in an effort to encourage students to want to read oppositionally. 
Copyright of Women's Studies in Communication is the property of Organization for Research on Women \& Communication and its content may not be copied or emailed to multiple sites or posted to a listserv without the copyright holder's express written permission. However, users may print, download, or email articles for individual use. 